\title{
Start Now to Design Citrus Groves for Mechanical Harvesting ${ }^{1}$
}

\section{Bob Rouse and Steve Futch ${ }^{2}$}

Change has kept the Florida citrus industry competitive during the last century. The Florida citrus industry is now facing one of its greatest challenges -- the change to mechanical harvesting or lose competitiveness in the global juice market. It is a general consensus among industry leaders that efficiencies in harvesting offer the greatest potential to reduce costs and keep our juice industry economically viable. Other tree crops (tart and sweet cherry, pistachios, prunes, olives) that would have been lost, have moved to mechanical harvesting to survive, but a generation of change was required and thinking had to be adjusted in lines with a commodity.

Generally, citrus groves in Florida were not designed and planted with mechanical harvesting in mind. Therefore, in order to gain the efficiencies necessary, changes to tree shape and grove architecture must occur. We have two paths to follow: 1) begin planting new groves designed for mechanical harvesting, and 2) retrofit existing groves that are suitable for mechanical harvesting.

\section{How Do We Start Preparing Groves for Mechanical Harvesting?}

The first change is to begin planting all new trees, both new and resets in groves suitable for conversion to mechanical harvesting, with high-headed trees. High-headed trees have longer than normal (16-inch) trunks, with the scaffold branching beginning at about 30 inches (Fig. 1). These high-headed trees are suited to accommodate mechanical harvesting by having higher tree skirts as well as providing greater trunk length to allow for trunk shaker attachment as well as having additional horticultural and practical advantages in the grove. Regardless of the harvesting machine utilized, a catch frame must fit under the tree to capture fruit for maximum cost efficiency. The second objective is to reshape existing trees to accommodate existing mechanical harvesting equipment. The important point to consider is that not all groves may be good candidates for mechanical harvesting and the first criteria should be to determine where mechanical harvesting may be utilized to obtain maximum harvesting efficiency. Groves determined not to be candidates for mechanical harvesting will have to be

1. This document is HS974, one of a series of the Horticultural Sciences Department, Florida Cooperative Extension Service, Institute of Food and Agricultural Sciences, University of Florida. Published September 2004. Visit the EDIS Web site at http://edis.ifas.ufl.edu.

2. Bob Rouse, associate professor, Horticultural Sciences Department, Southwest Florida REC, Immokalee, Florida and Steve Futch, Extension Agent IV, Horticultural Sciences Department, Citrus REC, Lake Alfred, Florida; Horticultural Sciences Department, Cooperative Extension Service, Institute of Food and Agricultural Sciences, University of Florida, Gainesville, 32611.

The Institute of Food and Agricultural Sciences (IFAS) is an Equal Employment Opportunity - Affirmative Action Employer authorized to provide research, educational information and other services only to individuals and institutions that function without regard to race, creed, color, religion, age, disability, sex, sexual orientation, marital status, national origin, political opinions or affiliations. For information on obtaining other extension publications, contact your county Cooperative Extension Service office. Florida Cooperative Extension Service / Institute of Food and Agricultural Sciences / University of Florida / Larry R. Arrington, Interim Dean 
hand harvested until a decision is made to remove the grove and replant with an architecture that maximizes mechanical harvesting efficiency.

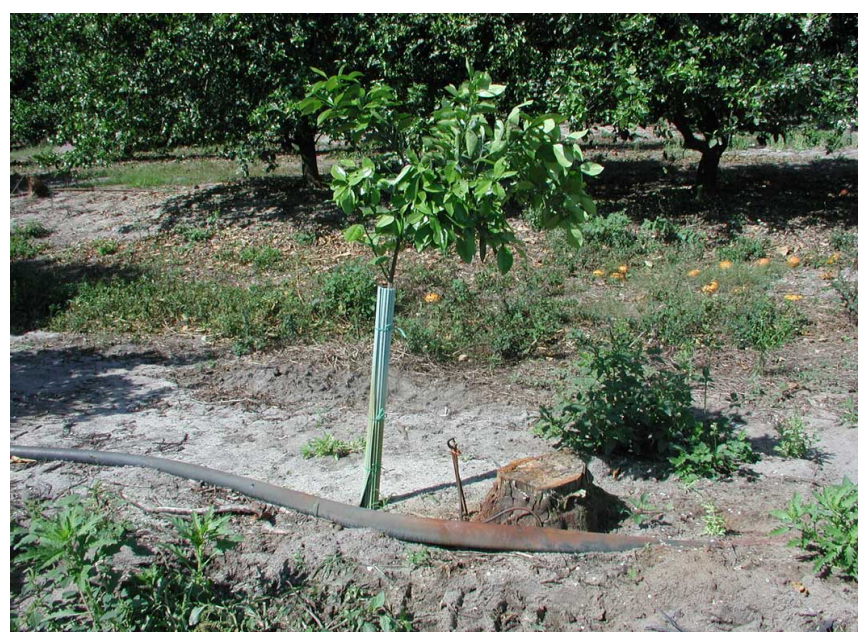

Figure 1. High-headed reset tree

New plantings should be designed along the criteria shown in the mechanical harvest grove concept (drawing) (Fig. 2).

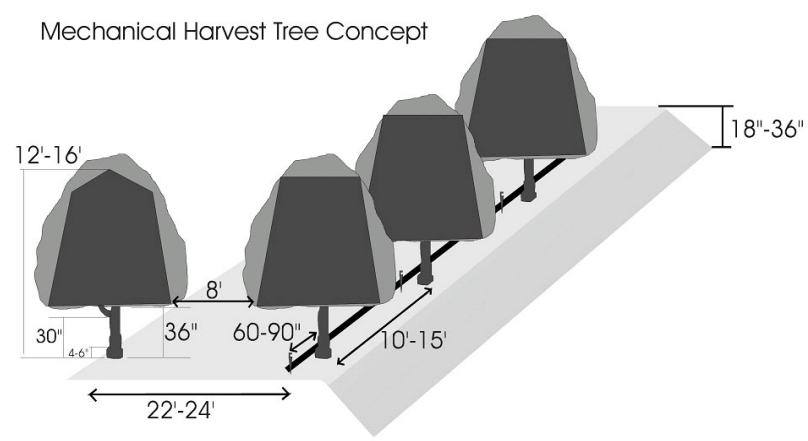

Figure 2. Mechanical harvest tree concept

- High-headed trees should be planted with scaffold branching starting at 30 inches and skirting maintained at the drip line at 36 inches.

- In-row spacing should be 10 to 15 feet and 22 to 24 feet between rows.

- Hedging down the row needs to maintain 8-foot width for passage of equipment.

- Tree heights limited to 16 feet with either flat or roof-top.

- Irrigation emitters need to be equal distance between trees in the row.
- Efficiency of machine is enhanced with longer rows.

- Turn space is need at end of row to accommodate large machines.

- In bedded groves, furrows must not be steep and must be suitable to accommodate heavy equipment.

\section{What are the Horticultural Advantages of High-Headed Trees?}

In addition to preparing for the future of mechanical harvesting and improving the recovery of fruit, there are many horticultural advantages to high-headed trees:

- Reduced herbicide damage to the tree without contact to low hanging foliage;

- Less exposure to brown rot and greasy spot with improved air drainage under the canopy;

- Reduce severity and frequency for mechanical skirting;

- More uniform wetting pattern of irrigation emitters with fewer obstacles from low hanging limbs;

- Irrigation emitters are visible for checking proper operation and maintenance;

- Fruit production will start sooner after planting because an older tree is planted.

This is not to suggest that high-headed trees won't require some change in attitude and adjustment in cultural practices. The following issues need to be addressed:

- Need a rigid nursery tree to withstand wind, mechanical, and pest pressure;

- Taller tree wraps will be needed and longer stakes if staking is necessary to support the tree at planting time;

- Taller wraps will house insects that attract predators that can pull over and break the tree; 
- Initial tree cost may be $\$ 0.50$ to $\$ 1.00$ more but production starts sooner.

\section{What About Converting My Existing Grove to Mechanical Harvesting?}

Not all groves are suitable for conversion to mechanical harvesting. It must be determined whether existing tree and grove structure (straight trunk and size, high scaffolds, tree health, age, grove layout, missing trees, grove size, etc.) would be cost effective to change. Additional costs will be incurred if irrigation emitters need to be relocated. If the trees can be skirted, hedged and topped, and meet the criteria of a grove design discussed above, it may be a good candidate. Skirting has been shown in several studies to only reduce yield a minimal amount the year skirting is done. Where mechanical harvesting has been used the past 10 years, no negative long-term effects have been observed. Limb breakage the first year is usually interior dead wood and live wood is no more than usually experienced with harvesting ladders. Any root damage is quickly recovered with no affects on yield.

\section{Can We Maintain Our Position in the World Orange Juice Market Without Mechanical Harvesting?}

The likely long-term answer is no. Costs have to come down and there is no reasonable expectation to think costs of hand harvesting will decline over time. Leaders in our industry see mechanical harvesting as an important change to reduce our costs enough to remain competitive. We have trained ourselves that every piece of fruit is money and we need every one. However, orange juice is a commodity and individual pieces of fruit are worth very little. As a commodity, we need to be thinking in efficiencies and that removal of 85 or $90 \%$ of the crop may be the most economical and puts the most money in the growers pocket. Gleaning, especially in today's market, may not be cost effective. Florida citrus growers need profit to stay in business and mechanical harvesting offers a viable option that must be considered. 